\title{
Analysis of differential gene-regulatory responses to zinc in human intestinal and placental cell lines
}

\author{
Kelly A. Jackson ${ }^{1}$, Ruth A. Valentine ${ }^{2}$, Jill A. McKay ${ }^{3}$, Daniel C. Swan ${ }^{1}$, John C. Mathers ${ }^{3}$ and \\ Dianne Ford ${ }^{1 *}$ \\ ${ }^{1}$ Human Nutrition Research Centre, Institute for Cell and Molecular Biosciences, Newcastle University, Newcastle upon Tyne NE2 \\ $4 H H, U K$ \\ ${ }^{2}$ Human Nutrition Research Centre, School of Dental Sciences, Newcastle University, Newcastle upon Tyne NE2 2BW, UK \\ ${ }^{3}$ Human Nutrition Research Centre, Institute for Ageing and Health, Newcastle University, Newcastle upon Tyne NE2 4HH, UK
}

(Received 28 February 2008 - Revised 19 August 2008 - Accepted 28 August 2008 - First published online 24 October 2008)

Transcriptomic studies are useful for elucidating molecular mechanisms through which changes in nutrient availability produce pleiotropic effects on whole-body and tissue physiology. To further the knowledge of gene-regulatory effects of $\mathrm{Zn}$ on tissues important for adult and fetal $\mathrm{Zn}$ nutrition, we analysed the responses of human intestinal Caco-2 and placental JAR cells to changes in $\mathrm{Zn}$ supply. Analysis of oligonucleotide microarrays demonstrated that, despite the analogous roles of the two tissues in nutrient transfer, different genes respond to changes in $\mathrm{Zn}$ availability in intestinal cells compared with placental cells. A number of $\mathrm{Fe}$ - and $\mathrm{Cu}$-related genes were identified as targets for regulation by $\mathrm{Zn}$, revealing potential mechanisms underlying reported dietary interactions between $\mathrm{Zn}$ and other metals. We established that there are fundamental differences in Zn-regulated transcriptional control in Caco-2 compared with JAR cells. We demonstrated that Zn-induced transcriptional activation of the metallothionein $2 \mathrm{~A}$ promoter occurs over different, and physiologically relevant, concentration ranges in Caco-2 and JAR cells, indicating that these cell lines sense changes in the extracellular Zn concentration over different ranges. Also, we established that mRNA levels of the Zn-responsive metal response element binding transcription factor (MTF)-1, and its homologue MTF-2, are regulated by Zn in Caco-2 but not JAR cells, which may in part underlie differential gene responses to $\mathrm{Zn}$ in intestinal and placental cells. The present study identified a number of novel molecular targets that may underlie symptoms associated with deficient or excessive $\mathrm{Zn}$ supply and highlighted the necessity of taking account of celland tissue-specific processes when investigating Zn-regulated gene expression in mammals.

Zinc: Caco-2 cells: JAR cells: Gene regulation

The essential dietary micronutrient $\mathrm{Zn}$ is a structural component of, and/or catalytic cofactor for, several hundred proteins, so plays critical roles in a diverse array of cellular processes $^{(1)}$. Zn is required for the catalytic activity of RNA polymerases and as a component of $\mathrm{Zn}$-finger domains of numerous transcription factors ${ }^{(2-4)}$, suggesting that alterations in $\mathrm{Zn}$ status can have potentially complex effects on gene expression. This view is supported by transcriptomic studies that document pleiotropic gene-regulatory effects of changes in $\mathrm{Zn}$ availability ${ }^{(5-14)}$.

The small intestine is the primary site of $\mathrm{Zn}$ homeostasis in mammals ${ }^{(15)}$, so a number of transcriptomic investigations have focused on the regulatory effects of dietary $\mathrm{Zn}$ supply on smallintestinal gene expression in rodent models ${ }^{(6,11,16,17)}$. By transferring nutrients between mother and fetus, the function of the placenta is analogous to that of the intestine. Observational studies in human subjects have suggested links between poor maternal $\mathrm{Zn}$ status and measures of pregnancy outcome ${ }^{(18)}$. Despite this evidence, no large-scale analyses of the effects of $\mathrm{Zn}$ availability on placental gene expression have been performed to date. An understanding of gene-regulatory responses to changes in
Zn availability in the human intestine and placenta will provide valuable information on the processes modulated by altered $\mathrm{Zn}$ nutrition and its potential impact on human health, particularly during fetal development.

We employed oligonucleotide microarrays to compare the effects of $\mathrm{Zn}$ on gene expression in the well-characterised human intestinal cell line Caco-2 and the human placental cell line JAR. We suggested previously that the regulation of expression of $\mathrm{Zn}$ transporter genes by $\mathrm{Zn}$ may occur over different concentration ranges in intestinal and placental cells, appropriate to the normal concentration of total extracellular $\mathrm{Zn}$ encountered by the two different tissues in vivo ${ }^{(19)}$. Whilst enterocytes in the intestine are exposed to the $\mathrm{Zn}$ concentration of the intestinal lumen, which is very variable and likely to be in the order of $100 \mu \mathrm{M}$ following a meal or nutrient supplement ${ }^{(20)}$, placental trophoblasts are exposed to much lower and less variable serum $\mathrm{Zn}$ concentrations of approximately $12-15 \mu \mathrm{M}^{(21)}$. In view of this hypothesis our experimental protocol was designed to allow us to establish if both cell types display parallel transcriptomic response profiles to $\mathrm{Zn}$ occurring at physiologically relevant

Abbreviations: IREB2, Fe-responsive element binding protein 2; MTF, metal response element binding transcription factor.

* Corresponding author: Dr Dianne Ford, fax + 44191222 7424, email dianne.ford@ncl.ac.uk 
concentrations. In contrast, our analysis demonstrates that a different repertoire of genes responds to changes in $\mathrm{Zn}$ availability in intestinal cells compared with placental cells. We also provide further evidence that $\mathrm{Zn}$ affects gene transcription differently in the Caco-2 compared with the JAR cell line by demonstrating differential regulation by $\mathrm{Zn}$ of both MT2A promoter activity and Zn-sensitive transcription factor expression. We suggest that the latter may be responsible, at least in part, for the differential gene responses to altered $\mathrm{Zn}$ supply in intestinal and placental cells. Interestingly, in relation to reports of nutrient interactions between $\mathrm{Zn}$ and other metals, our microarray analyses identified a number of $\mathrm{Fe}$ - and $\mathrm{Cu}$-related genes as targets for regulation by $\mathrm{Zn}$ in intestinal or placental cells.

\section{Methods}

\section{Cell culture}

Caco-2 and JAR cells were cultured as described previously ${ }^{(20)}$. Absence of mycoplasma contamination was confirmed using the Venor GeM detection kit (Cambio Ltd, Cambridge, Cambs, UK). Zn was added to confluent JAR monolayers or differentiated Caco-2 monolayers in six replicate $75 \mathrm{~cm}^{2}$ flasks. Either $7 \mathrm{~d}$ (JAR) or $14 \mathrm{~d}$ (Caco-2) post-seeding, culture medium was replaced with $15 \mathrm{ml}$ basal medium (about $3 \mu \mathrm{M}-\mathrm{Zn}$, assessed by atomic absorption spectroscopy) or medium supplemented to $12 \mu \mathrm{M}$ or $100 \mu \mathrm{M}$ with $\mathrm{ZnCl}_{2}$; cells were then cultured for 12 or $24 \mathrm{~h}$.

\section{Preparation of RNA samples for microarray analysis}

Total RNA was extracted from cells using TRIzol reagent (Invitrogen Corp., Carlsbad, CA, USA). Traces of genomic DNA were digested by incubation with RNase-free DNaseI (Roche, Basel, Switzerland), then RNA was extracted using phenol-chloroform. RNA from the six replicate flasks was pooled, and then concentration was determined using a NanoDrop $^{\mathrm{TM}}$ spectrophotometer (NanoDrop Technologies, Thermo Fisher Scientific Inc., Pittsburgh, PA, USA). RNA quality was confirmed by denaturing agarose gel electrophoresis and also on an Agilent 2100 Bioanalyzer (Agilent Technologies, Inc., Santa Clara, CA, USA), accepting an RNA Integrity Number $(\mathrm{RIN})>9$.

\section{Preparation of Arabidopsis thaliana external control cRNA}

Total RNA extracted from Arabidopsis thaliana leaves was reverse transcribed to cDNA using SuperScript III RNase $\mathrm{H}^{-}$ enzyme (Invitrogen Corp.). PCR amplification was performed over thirty cycles $\left(95^{\circ} \mathrm{C}\right.$ for $30 \mathrm{~s} ; 55^{\circ} \mathrm{C}$ for $30 \mathrm{~s}, 72^{\circ} \mathrm{C}$ for $\left.90 \mathrm{~s}\right)$, using ThermoStart DNA polymerase (ABgene Ltd, Epsom, Surrey, UK) (forward primer sequence: GCATCAACGCGAAAACAGTTGG; reverse primer sequence: CTTATACTCCCTTCGATGTACC). The cDNA fragment was subcloned into the pCR2.1TOPO vector (Invitrogen Corp.) to give the plasmid pCR2.1TOPO-ara_control. The construct was linearised $3^{\prime}$ of the insert using Bam $\mathrm{HI}$, then complementary RNA was transcribed from the T7 promoter using the mMessage mMachine kit (Applied Biosystems/Ambion, Austin, TX,
USA). A poly(A)-tail was added to the cRNA transcript using the Ambion poly(A)-tailing kit.

\section{MWG custom microarrays}

Human low-density custom glass microarray slides were obtained from MWG Biotech Ltd (Ebersberg, Germany) and were spotted with duplicate arrays of 50-mer oligonucleotides. Each duplicate array incorporated 190 experimental human genes, nine human housekeeping genes and two $A$. thaliana control genes. One of the A. thaliana genes was utilised as an external control gene, which was spiked into array labelling reactions, whilst the other was used as a negative control gene to measure background levels of fluorescence on array slides.

\section{Preparation of labelled cDNA for microarray hybridisation}

Labelled cDNA samples for microarray analyses were prepared using the CyScribe amino-allyl post-labelling kit (Amersham/GE Healthcare). Each experimental and reference sample was labelled in duplicate, once with $\mathrm{Cy} 3$ and once with Cy5. Reverse transcription reactions contained $20 \mu \mathrm{g}$ total RNA plus $2 \cdot 8 \mathrm{ng}$ synthetic poly(A)-tailed $A$. thaliana external control RNA (equivalent to 1000 spike copies/cell). Measurements of cDNA yield and CyDye incorporation were by spectrophotometry. $\mathrm{Cy} 3$ and $\mathrm{Cy} 5$ incorporation was measured using absorbance settings of 550 and $649 \mathrm{~nm}$ respectively.

\section{Hybridisation and scanning protocols}

Equal amounts $(40 \mathrm{pmol})$ of Cy3- and Cy5-labelled experimental and reference cDNA were hybridised to array slides. Two independent hybridisations were performed for each reference $v$. experimental comparison, each with genes spotted in duplicate, using a dye-swap approach. Hybridisations were carried out using an HS4800 Automatic Hyb Chamber (Tecan, Lyon, France). Microarray slides were pre-hybridised in buffer containing $3 \times$ saline-sodium citrate (SSC), $0.15 \% \mathrm{SDS}$, for a total of $90 \mathrm{~s}$ at $42^{\circ} \mathrm{C}$. Hybridisation was performed at $42^{\circ} \mathrm{C}$ for $16 \mathrm{~h}$ with low agitation. Slides were washed at $30^{\circ} \mathrm{C}$ for $30 \mathrm{~s}$ with $2 \times \mathrm{SSC}, 0 \cdot 1 \% \mathrm{SDS}$, followed by $1 \times \mathrm{SSC}$, then $0.5 \times \mathrm{SSC}$. Scanning was performed with a GenePix 4000B confocal laser scanner (Molecular Devices, Sunnyvale, CA, USA), using laser excitation at $532 \mathrm{~nm}$ for $\mathrm{Cy} 3$ and $635 \mathrm{~nm}$ for Cy5. Photo-multiplier tube gain was optimised for each slide so that detection of low and high intensity signals was balanced and saturation tolerance was set at $0.005 \%$ to avoid pixel saturation. GenePix Pro 6.0 software (Molecular Devices) was used to extract raw data from the images.

\section{Microarray data normalisation and analysis}

Gene expression levels were normalised and analysed using GeneSpring GX 7.3 software (Agilent Technologies, Inc.). A cut-off was applied to discard data from weak signals; present calls were determined as signals that had intensity values in either the $\mathrm{Cy} 3$ or $\mathrm{Cy} 5$ channel greater than the mean intensity of the A. thaliana negative control spots plus two times the standard deviation. Expression ratios (i.e. Cy5:Cy3, or Cy3:Cy5 for dye swaps) for each gene were normalised 
using factors calculated from the median intensity ratios of the A. thaliana external control gene and a panel of nine housekeeping genes. To estimate the expected variance of ratios of non-regulated genes, $95 \%$ CI were calculated using the mean and standard deviation of the normalised set of housekeeping genes. Genes were considered up- or down-regulated (i.e. differentially expressed between reference and experimental samples) if they had: (i) an average ratio, calculated from the four replicates, outside of the $95 \% \mathrm{CI}$, or (ii) ratios outside of the $95 \% \mathrm{CI}$ in at least three out of four replicates. Statistical analysis was by Student's $t$ test with a BenjaminiHochberg multiple testing correction. Genes with $P<0.05$ were determined to be significantly regulated by the experimental $\mathrm{Zn}$ treatment. All statistical analyses were performed using log-transformed data. Microarray data were annotated to MIAME (minimum information about a microarray experiment) standard and have been deposited in the ArrayExpress database (www.ebi.ac.uk/arrayexpress; EMBL - European Bioinformatics Institute, Cambridge, Cambs, UK) with the accession number E-MEXP-1064.

\section{Real-time reverse transcriptase polymerase chain reaction for} validation of microarray results

Reverse transcription was carried out with SuperScript III RNase $\mathrm{H}^{-} \mathrm{RT}$ (Invitrogen), using random hexamer primers and $2.5 \mu \mathrm{g}$ DNase-treated RNA. Real-time PCR was performed using SYBR-Green I Master Mix (Roche) with the Lightcycler 480 (Roche) for fluorescence detection. Cycling conditions were as follows: denaturation at $95^{\circ} \mathrm{C}$ for $5 \mathrm{~min}$, then fortyfive cycles of $95^{\circ} \mathrm{C}$ for $10 \mathrm{~s} ; 53^{\circ} \mathrm{C}$ or $60^{\circ} \mathrm{C}$ for $15 \mathrm{~s} ; 72^{\circ} \mathrm{C}$ for $6 \mathrm{~s}$. Primer sequences are listed in Supplementary Table 1. Expression levels were normalised to expression levels of glyceraldehyde-3-phosphate dehydrogenase. Primer specificity was assured by a single melting curve peak. Statistical analysis of data (n 3) was by one-way ANOVA followed by Dunnett's post test.

\section{Generation of reporter plasmid constructs}

The -358 to +40 region of the MT2A promoter was subcloned into the vector pBlueTOPO (Invitrogen Corp.), upstream of the $\beta$-galactosidase reporter gene, as described previously ${ }^{(22)}$.

\section{Reporter gene assay}

Transfection and measurement of $\beta$-galactosidase reporter gene activity in Caco- 2 and JAR cells were as described previously for Caco- 2 cells ${ }^{(22)}$. The protein concentration of cell lysates was determined using the Bradford assay (Bio-Rad, Hercules, CA, USA).

\section{Results}

Comparison of global gene responses to zinc in intestinal and placental cell lines

We employed dual-label (Cy3, Cy5), low-density oligonucleotide microarrays to examine changes in gene expression levels between experimental cells grown under $\mathrm{Zn}$-supplemented conditions $(12 \mu \mathrm{M}$ or $100 \mu \mathrm{M}$ extracellular $\mathrm{Zn})$ and reference cells grown in basal culture medium $(3 \mu \mathrm{M}$ extracellular $\mathrm{Zn}$ ), for either 12 or $24 \mathrm{~h}$. Microarray slides incorporated two A. thaliana control genes, one of which was used as a negative control (to measure background levels of fluorescence on array slides), whilst the other was utilised as an external spike-in control gene (to correct for effects of systematic variations in the microarray data). Poly(A)-tailed cRNA corresponding to the A. thaliana external control gene was spiked in equal quantities into experimental and reference microarray sample labelling reactions and expression ratios of each gene were normalised to expression ratios of nine housekeeping genes spotted on the arrays and the Arabidopsis external control. Only genes classified as present (signal intensities in reference or experimental samples greater than the mean of the negative control spots plus $2 \mathrm{SD}$ ) were included for analysis. Data from four replicate spots were used to calculate the average expression ratio of each gene under each experimental condition. Identification of differentially expressed genes was based on $95 \%$ CI, calculated two-sided from the log-transformed mean expression ratio $(\mu)$ of the panel of nine housekeeping genes $(\mu \pm 1.96 \times \mathrm{SD})$. Lists of genes identified as differentially expressed in Caco- 2 and JAR cells under each experimental condition are provided in Tables 1 and 2. All information relating to these microarray experiments, including a complete dataset of expression ratios for all genes and experiments, can be viewed at www.ebi.ac.uk/ arrayexpress (accession number: E-MEXP-1064).

In the $12 \mathrm{~h}$ experiments, supplementation of Caco- 2 and JAR cells with $100 \mu \mathrm{M}-\mathrm{ZnCl}_{2}$ led to differential expression (outside the $95 \% \mathrm{CI}$ ) of seven and three genes respectively, whilst supplementation with $12 \mu \mathrm{M}-\mathrm{ZnCl}_{2}$ led to no detectable changes in the JAR cell line. Gene responses to treatment with $12 \mu \mathrm{M}-\mathrm{ZnCl}_{2}$ for $12 \mathrm{~h}$ were not measured in the Caco-2 cell line because insufficient microarray slides were available. In the $24 \mathrm{~h}$ experiments, following exposure to $100 \mu \mathrm{M}-\mathrm{ZnCl}_{2}$, eleven genes in the Caco- 2 cell line and fourteen genes in the JAR cell line were identified as differentially expressed, whilst exposure to $12 \mu \mathrm{M}-\mathrm{ZnCl}_{2}$ led to detectable changes in the expression of only six genes in the Caco- 2 cell line and two genes in the JAR cell line. Interestingly, with the exception of the metallothionein genes (MT1H, MT2A, MT3), the lists of genes identified as differentially expressed in Caco-2 and JAR cells did not overlap. In general the observed changes in gene expression in Caco-2 and JAR cells treated with $\mathrm{Zn}$ concentrations of $12 \mu \mathrm{M}$ and $100 \mu \mathrm{M}$ were small and all were less than 2 -fold. The exceptions to this generalisation were the MT genes (isoforms MT1H, MT2A and MT3), which were up-regulated at $100 \mu \mathrm{M}-\mathrm{Zn}$ by approximately $5-6$-fold in Caco- 2 cells and 7-8-fold in JAR cells.

A number of genes related to transport or metabolism of $\mathrm{Cu}$ and $\mathrm{Fe}$ were identified as differentially expressed in either Caco-2 or JAR cells. Following exposure to $100 \mu \mathrm{M}-\mathrm{Zn}$ for $24 \mathrm{~h}$, the expression of hephaestin mRNA was down-regulated in Caco-2 cells, whilst ceruloplasmin expression was up-regulated in JAR cells under the same conditions. In addition, expression levels of transferrin, Fe-responsive element binding protein 2 (IREB2) and the $\mathrm{Cu}$ transporter hCTR2 were all increased in JAR cells exposed to $100 \mu \mathrm{M}-\mathrm{Zn}$ for $24 \mathrm{~h}$, whilst the $\mathrm{Cu}$ transporter ATP7B was down-regulated in these cells following $24 \mathrm{~h}$ exposure to $12 \mu \mathrm{M}$ extracellular $\mathrm{Zn}$. 
Table 1. Genes identified as differentially expressed in Caco-2 cells by DNA microarray hybridisation following exposure to $12 \mu \mathrm{M}$ or $100 \mu \mathrm{M}$ extracellular zinc concentrations for 12 or $24 \mathrm{~h}$

\begin{tabular}{|c|c|c|c|c|c|}
\hline Sample* & Gene† & Encoded protein $\ddagger$ & Fold change§ & SEM\| & $P q$ \\
\hline Caco-2, $12 \mathrm{~h}, 12 \mu \mathrm{M}-\mathrm{Zn}$ & & Not tested & & & \\
\hline Caco-2, $12 \mathrm{~h}, 100 \mu \mathrm{M}-\mathrm{Zn}$ & $\begin{array}{l}\text { NM_005953 } \\
\text { NM_005954 } \\
\text { NM_005951 } \\
\text { NM_002483 } \\
\text { K00558 } \\
\text { NM_002083 } \\
\text { NM_001134 }\end{array}$ & $\begin{array}{l}\text { Metallothionein 2A (MT2A) } \\
\text { Metallothionein 3 (MT3) } \\
\text { Metallothionein 1H (MT1H) } \\
\text { Carcinoembryonic antigen-related cell adhesion molecule } \\
\alpha \text {-Tubulin } \\
\text { Glutathione peroxidase 2, gastrointestinal (GPX2) } \\
\alpha \text {-Fetoprotein (AFP) }\end{array}$ & $\begin{array}{l}+7 \cdot 80 \\
+6 \cdot 41 \\
+5 \cdot 44 \\
+1 \cdot 70 \\
+1.42 \\
+1.41 \\
-1.64\end{array}$ & $\begin{array}{l}1.07 \\
0.90 \\
0.72 \\
0.25 \\
0.12 \\
0.12 \\
0.23\end{array}$ & $\begin{array}{l}0.0006 \\
0.0009 \\
0.0010 \\
0.0338 \\
0.0044 \\
0.0249 \\
0.0384\end{array}$ \\
\hline Caco-2, $24 \mathrm{~h}, 12 \mu \mathrm{M}-\mathrm{Zn}$ & $\begin{array}{l}\text { NM_003122 } \\
\text { NM_005694 } \\
\text { NM_005628 } \\
\text { BC032801 } \\
\text { NM_001693 } \\
\text { NM_001134 }\end{array}$ & $\begin{array}{l}\text { Serine protease inhibitor, Kazal type } 1 \text { (SPINK1) } \\
\text { Cytochrome c oxidase assembly protein } \\
\text { Solute carrier SLC1A5 (neutral amino acid transporter) } \\
\text { Fatty acid binding protein 1, liver (L-FABP) } \\
\text { Lysosomal ATPase, H+transporting, V1 subunit B } \\
\alpha \text {-Fetoprotein (AFP) }\end{array}$ & $\begin{array}{l}-1.24 \\
-1.31 \\
-1.35 \\
-1.35 \\
-1.44 \\
-1.54\end{array}$ & $\begin{array}{l}0.04 \\
0.09 \\
0.05 \\
0.08 \\
0.05 \\
0.12\end{array}$ & $\begin{array}{l}0.0064 \\
0.0272 \\
0.0043 \\
0.0136 \\
0.0020 \\
0.0106\end{array}$ \\
\hline Caco-2, $24 \mathrm{~h}, 100 \mu \mathrm{M}-\mathrm{Zn}$ & $\begin{array}{l}\text { NM_005953 } \\
\text { NM_005951 } \\
\text { NM_005954 } \\
\text { AF141359 } \\
\text { X14850 } \\
\text { Z44894 } \\
\text { NM_001675 } \\
\text { D11966 } \\
\text { NM_001134 } \\
\text { NM_014799 } \\
\text { NM_004063 }\end{array}$ & $\begin{array}{l}\text { Metallothionein 2A (MT2A) } \\
\text { Metallothionein 1H (MT1H) } \\
\text { Metallothionein } 3(\mathrm{MT} 3) \\
\text { Sodium/hydrogen exchanger isoform } 1 \text { (APNH) } \\
\text { Histone H2A } \\
\text { Infant brain cDNA clone c-2cb12 } \\
\text { Activating transcription factor } 4 \text { (ATF4) } \\
\text { Liver HepG2 cell line cDNA clone s129 } \\
\alpha-\text {-Fetoprotein (AFP) } \\
\text { Hephaestin ferroxidase } \\
\text { Cadherin } 17 \text { (liver-intestine) }\end{array}$ & $\begin{array}{l}+6.45 \\
+5.83 \\
+5.59 \\
+1.55 \\
+1.42 \\
+1.39 \\
-1.29 \\
-1.35 \\
-1.41 \\
-1.47 \\
-1.71\end{array}$ & $\begin{array}{l}1.88 \\
2.07 \\
1.47 \\
0.02 \\
0.05 \\
0.11 \\
0.05 \\
0.06 \\
0.07 \\
0.15 \\
0.27\end{array}$ & $\begin{array}{l}0.0062 \\
0.0118 \\
0.0061 \\
0.0001 \\
0.0018 \\
0.0249 \\
0.0059 \\
0.0062 \\
0.0068 \\
0.0291 \\
0.0408\end{array}$ \\
\hline
\end{tabular}

* RNA samples extracted from Caco-2 cells exposed for the indicated time period to the indicated extracellular $\mathrm{Zn}$ concentration.

†GenBank accession number.

$\ddagger$ Name of encoded protein.

§Magnitude of changes observed by array, increased $(+)$ or decreased $(-)$ relative to expression levels in control cells $(3 \mu \mathrm{M}-\mathrm{Zn})$.

$\|$ Each gene $n 4$.

I| By Student's $t$ test.

Table 2. Genes identified as differentially expressed in JAR cells by DNA microarray hybridisation following exposure to $12 \mu \mathrm{M}$ or $100 \mu \mathrm{M}$ extracellular zinc concentrations for 12 or $24 \mathrm{~h}$

\begin{tabular}{|c|c|c|c|c|c|}
\hline Sample* & Gene† & Encoded protein $\ddagger$ & Fold change§ & SEM\| & $P q$ \\
\hline JAR, $12 \mathrm{~h}, 12 \mu \mathrm{M}-\mathrm{Zn}$ & & No response & & & \\
\hline JAR, $12 \mathrm{~h}, 100 \mu \mathrm{M}-\mathrm{Zn}$ & $\begin{array}{l}\text { NM_005954 } \\
\text { NM_005951 } \\
\text { NM_005953 }\end{array}$ & $\begin{array}{l}\text { Metallothionein } 3(\mathrm{MT} 3) \\
\text { Metallothionein 1H (MT1H) } \\
\text { Metallothionein 2A (MT2A) }\end{array}$ & $\begin{array}{l}+6 \cdot 96 \\
+5.56 \\
+5 \cdot 39\end{array}$ & $\begin{array}{l}1.488 \\
0.834 \\
1.652\end{array}$ & $\begin{array}{l}0.0025 \\
0.0013 \\
0.0094\end{array}$ \\
\hline JAR, $24 \mathrm{~h}, 12 \mu \mathrm{M}-\mathrm{Zn}$ & $\begin{array}{l}\text { NM_005953 } \\
\text { NM_000053 }\end{array}$ & $\begin{array}{l}\text { Metallothionein 2A (MT2A) } \\
\text { Wilson disease, copper transporting protein (ATP7B) }\end{array}$ & $\begin{array}{l}+1.73 \\
-1.50\end{array}$ & $\begin{array}{l}0.166 \\
0.127\end{array}$ & $\begin{array}{l}0.0106 \\
0.0165\end{array}$ \\
\hline JAR, $24 \mathrm{~h}, 100 \mu \mathrm{M}-\mathrm{Zn}$ & $\begin{array}{l}\text { NM_005953 } \\
\text { NM_005954 } \\
\text { NM_005951 } \\
\text { NM_000096 } \\
\text { NM_000281 } \\
\text { NM_001063 } \\
\text { NM_021194 } \\
\text { NM_000304 } \\
\text { NM_001172 } \\
\text { AK022859 } \\
\text { XM_039114 } \\
\text { U83461 } \\
\text { NM_000975 } \\
\text { NM 002415 }\end{array}$ & $\begin{array}{l}\text { Metallothionein 2A (MT2A) } \\
\text { Metallothionein } 3(\mathrm{MT} 3) \\
\text { Metallothionein 1H (MT1H) } \\
\text { Ceruloplasmin ferroxidase } \\
\text { 6-Pyruvoyl-tetrahydropterin synthase, cofactor of HNF1 } \alpha \\
\text { Transferrin } \\
\text { Solute carrier SLC30A1 (zinc transporter ZnT1) } \\
\text { Peripheral myelin protein } 22 \text { (PMP22) } \\
\text { Arginase, type II, encoding mitochondrial protein } \\
\text { FLJ12797 cDNA clone } \\
\text { Iron-responsive element binding protein } 2 \text { (IREB2) } \\
\text { Copper uptake protein (hCTR2) } \\
\text { Ribosomal protein L11 } \\
\text { Macrophage migration inhibitory factor }\end{array}$ & $\begin{array}{l}+7.84 \\
+7.31 \\
+7.12 \\
+1.92 \\
+1.88 \\
+1.88 \\
+1.82 \\
+1.77 \\
+1.69 \\
+1.50 \\
+1.37 \\
+1.34 \\
-1.21 \\
-1.28\end{array}$ & $\begin{array}{l}0.99 \\
1.25 \\
0.58 \\
0.33 \\
0.13 \\
0.13 \\
0.08 \\
0.08 \\
0.05 \\
0.16 \\
0.07 \\
0.10 \\
0.07 \\
0.04\end{array}$ & $\begin{array}{l}0.0005 \\
0.0013 \\
0.0002 \\
0.0297 \\
0.0026 \\
0.0026 \\
0.0007 \\
0.0009 \\
0.0005 \\
0.0299 \\
0.0084 \\
0.0255 \\
0.0412 \\
0.0049\end{array}$ \\
\hline
\end{tabular}

* RNA samples extracted from JAR cells exposed for the indicated time period to the indicated extracellular $\mathrm{Zn}$ concentration.

† GenBank accession number.

$\ddagger$ Name of encoded protein.

$\S$ Magnitude of changes observed by array, increased $(+)$ or decreased $(-)$ relative to expression levels in control cells $(3 \mu \mathrm{M}-\mathrm{Zn})$.

\|l Each gene $n 4$.

ๆ By Student's $t$ test. 
Validation of changes in gene expression by real-time reverse transcriptase polymerase chain reaction

We selected six of the candidate genes identified from microarray analyses of Caco-2 and JAR cells for verification by real-time RT-PCR (Supplementary Table 1). These genes comprised the following, all related to the transport and/or metabolism of dietary essential metals: Zn transporter ZnT1; multi-copper ferroxidases hephaestin and ceruloplasmin; $\mathrm{Cu}$ transporters hCTR2 and ATP7B; Fe-regulated transcription factor IREB2. Gene expression levels were normalised to the expression of glyceraldehyde-3-phosphate dehydrogenase. Real-time PCR results confirmed the up-regulation of both $\mathrm{ZnT1}$ and IREB2 in JAR cells exposed to $100 \mu \mathrm{M}-\mathrm{Zn}$ for $24 \mathrm{~h}$, detected via microarray analysis, and also demonstrated a significant increase in the expression of both genes at $12 \mu \mathrm{M}$ $\mathrm{Zn}$ (Table 3). The down-regulation of hephaestin mRNA expression in Caco-2 cells exposed to $100 \mu \mathrm{M}-\mathrm{Zn}$ for $24 \mathrm{~h}$, detected by microarray analysis, was also confirmed by realtime PCR. For the remaining genes, results of microarray and real-time PCR analyses did not correlate. Our published data demonstrate a robust up-regulation of MT2A at increased extracellular $\mathrm{Zn}$ concentrations $(100 \mu \mathrm{M}$ and $150 \mu \mathrm{M})$ in Caco2 and JAR cells ${ }^{(19,20,23)}$, so we did not repeat confirmation of metallothionein responses to $\mathrm{Zn}$ in the present study.

\section{Profile of zinc regulation of the human MT2A promoter in} Caco-2 and JAR cell lines

To investigate differences between the regulation profile of a well-characterised Zn-responsive gene in human intestinal and placental cells, we examined the effect of a range of extracellular $\mathrm{Zn}$ concentrations on transcriptional activity of the highly Zn-responsive human MT2A promoter in both Caco-2 and JAR cell lines. A $\beta$-galactosidase reporter construct incorporating the MT2A promoter was transfected transiently into Caco-2 and JAR cells and cells were exposed for $24 \mathrm{~h}$ to culture medium containing $3-150 \mu \mathrm{M}-\mathrm{Zn}$ as $\mathrm{ZnCl}_{2}$. The MT2A promoter-reporter construct showed concentration-dependent transcriptional activation by $\mathrm{Zn}$ in both Caco-2 and JAR cells, but the profile of concentration-dependence differed between the two cell lines (Fig. 1). In Caco-2 cells, the MT2A promoter was fairly refractory to Zn concentrations below $75 \mu \mathrm{M}$, whilst promoter activity in JAR cells was responsive to much lower $\mathrm{Zn}$ concentrations. For this comparison, reporter gene activity in each cell line was normalised to the corresponding value measured at $3 \mu \mathrm{M}-\mathrm{Zn}$, to exclude any influence of transfection efficiency. A low level of $\beta$-galactosidase activity (approximately $10 \%$ of the activity measured at $3 \mu \mathrm{M}-\mathrm{Zn}$ ) measured in both Caco-2 and JAR cells transfected with a corresponding negative control reporter construct, containing no promoter insert ${ }^{(23)}$, was unchanged by extracellular $\mathrm{Zn}$ concentration. This observation excludes the possibility that the differential effect of $\mathrm{Zn}$ on $\beta$-galactosidase activity observed in the two cell lines could be attributed to any effect on endogenous gene expression or to any promoter-independent effect on reporter gene activity. These observations are consistent with the different extracellular $\mathrm{Zn}$ concentrations sensed by the two corresponding tissues in vivo. It is notable that the transcriptional activation of the MT2A promoter detected using our reporter gene approach was in excellent agreement with the pattern and magnitude of the response of the MT2A gene to $\mathrm{Zn}$ indicated by the microarray analysis (Fig. 1).

Table 3. Comparison of fold-changes in gene expression induced by zinc treatment in Caco-2 and JAR cells as detected by DNA microarray hybridisation or real-time PCR

(Mean values with their standard errors)

\begin{tabular}{|c|c|c|c|c|c|c|}
\hline \multirow[b]{3}{*}{ Gene† } & \multirow[b]{3}{*}{ Encoded protein $\ddagger$} & \multirow[b]{3}{*}{ RNA sample§ } & \multicolumn{4}{|c|}{ Fold change\|l } \\
\hline & & & \multicolumn{2}{|c|}{ Microarray } & \multicolumn{2}{|c|}{ Real-time PCR $+\dagger$} \\
\hline & & & Mean & SEM & Mean & SEM \\
\hline \multirow[t]{2}{*}{ NM_014799 } & Hephaestin & Сaco-2, $24 \mathrm{~h}, 12 \mu \mathrm{M}-\mathrm{Zn}$ & -1.01 & 0.22 & -1.02 & 0.04 \\
\hline & & Caco-2, $24 \mathrm{~h}, 100 \mu \mathrm{M}-\mathrm{Zn}$ & $-1.47^{\star}$ & 0.15 & $-1 \cdot 12^{*}$ & 0.02 \\
\hline \multirow[t]{2}{*}{ NM_021194 } & $\mathrm{ZnT} 1$ & JAR, $24 \mathrm{~h}, 12 \mu \mathrm{M}-\mathrm{Zn}$ & +1.04 & 0.04 & $+1.32^{*}$ & 0.03 \\
\hline & & JAR, $24 \mathrm{~h}, 100 \mu \mathrm{M}-\mathrm{Zn}$ & $+1 \cdot 82^{*}$ & 0.08 & $+2 \cdot 39^{*}$ & 0.02 \\
\hline \multirow[t]{2}{*}{ U83461 } & hCTR2 & JAR, $24 \mathrm{~h}, 12 \mu \mathrm{M}-\mathrm{Zn}$ & $-1 \cdot 18$ & 0.08 & $+1 \cdot 25^{*}$ & 0.02 \\
\hline & & JAR, 24 h, $100 \mu M-Z n$ & $+1 \cdot 34^{*}$ & 0.10 & $-1 \cdot 20^{*}$ & 0.01 \\
\hline \multirow[t]{2}{*}{ NM_000053 } & ATP7B & JAR, $24 \mathrm{~h}, 12 \mu \mathrm{M}-\mathrm{Zn}$ & $-1 \cdot 50^{*}$ & 0.13 & $+1 \cdot 25^{*}$ & 0.02 \\
\hline & & JAR, $24 \mathrm{~h}, 100 \mu \mathrm{M}-\mathrm{Zn}$ & $+1 \cdot 25$ & 0.26 & $+1 \cdot 73^{*}$ & 0.05 \\
\hline \multirow[t]{2}{*}{ NM_000096 } & Ceruloplasmin & JAR, $24 \mathrm{~h}, 12 \mu \mathrm{M}-\mathrm{Zn}$ & $-1 \cdot 13$ & 0.53 & $+1 \cdot 19^{*}$ & 0.01 \\
\hline & & JAR, $24 \mathrm{~h}, 100 \mu \mathrm{M}-\mathrm{Zn}$ & $+1.92^{*}$ & 0.33 & $-1 \cdot 14$ & 0.03 \\
\hline \multirow[t]{2}{*}{ NM_004136 } & IREB2 & JAR, $24 \mathrm{~h}, 12 \mu \mathrm{M}-\mathrm{Zn}$ & -1.02 & 0.26 & $+1.55^{\star}$ & 0.05 \\
\hline & & JAR, $24 \mathrm{~h}, 100 \mu \mathrm{M}-\mathrm{Zn}$ & $+1.37^{\star}$ & 0.07 & $+1.95^{\star}$ & 0.06 \\
\hline
\end{tabular}

- , Reduced expression; ZnT, Zn transporter; +, increased expression; CTR, Cu transporter; IREB2, Fe-responsive element binding protein 2.

* Statistically significant $(P<0.05)$.

† GenBank accession number.

$\ddagger$ Name of encoded protein.

$\S$ Sample analysed, indicating cell line, $\mathrm{Zn}$ concentration and exposure time.

\| Fold-changes, compared with expression levels in cells exposed to $3 \mu \mathrm{M}$ extracellular Zn for the corresponding time-point, for $n 4$ (microarray) or $n 3$ (real-time PCR).

I Statistical analysis for microarray data was by Student's $t$ test followed by Benjamini-Hochberg multiple testing correction (microarray), using an expression ratio of 1 as the control value.

t† Statistical analysis for real-time PCR data was by one-way ANOVA followed by Dunnett's post-test. 


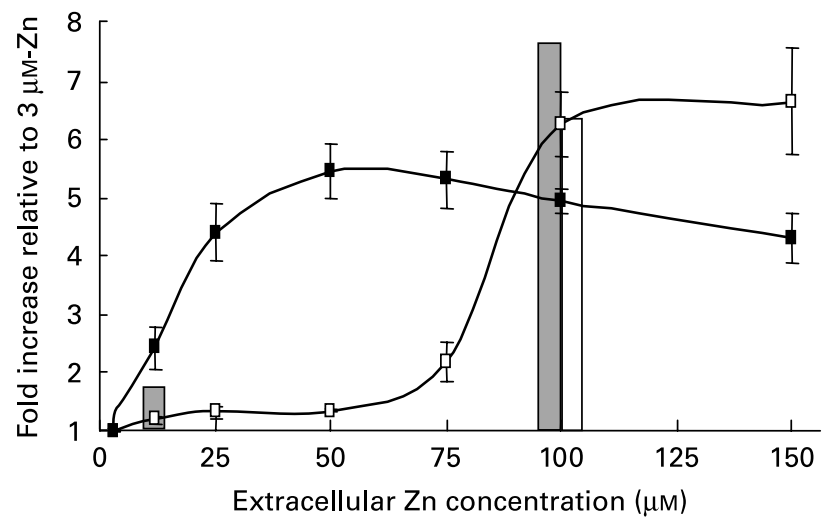

Fig. 1. Concentration dependence of transcriptional activation of the human MT2A promoter by $\mathrm{Zn}$ in Caco-2 (- $\square-)$ and JAR (- -$)$ cells. Cells were exposed to culture medium containing $3-150 \mu \mathrm{M}-\mathrm{Zn}$ as $\mathrm{ZnCl}_{2}$ for $24 \mathrm{~h}$. Promoter activity was detected as activity in cell lysates of a $\beta$-galactosidase reporter gene immediately downstream of the MT2A promoter $(-358$ to +40 ) in the vector pBlue-TOPO (Invitrogen), assayed using the substrate chlorophenol red- $\beta$-D-galactopyranoside. Data are normalised to activity at $3 \mu \mathrm{M}-\mathrm{Zn}$. Values are means $(n 9-30)$, with standard errors represented by vertical bars. The bars show the fold-increase in MT2A mRNA at $12 \mu \mathrm{M}$ - and $100 \mu \mathrm{M}-\mathrm{Zn}$ in Caco-2 ( $\square$ ) and JAR ( $\square$ ) cells, compared with $3 \mu \mathrm{M}-\mathrm{Zn}$, at $24 \mathrm{~h}$ detected by DNA microarray hybridisation.

Microarray analysis detected an increase in MT2A mRNA expression in Caco-2 cells at $100 \mu \mathrm{M}-\mathrm{Zn}$ but not at $12 \mu \mathrm{M}$ $\mathrm{Zn}$ (compared with $3 \mu \mathrm{M}-\mathrm{Zn}$ ). In JAR cells the MT2A mRNA was increased at both $12 \mu \mathrm{M}$ - and $100 \mu \mathrm{M}-\mathrm{Zn}$.
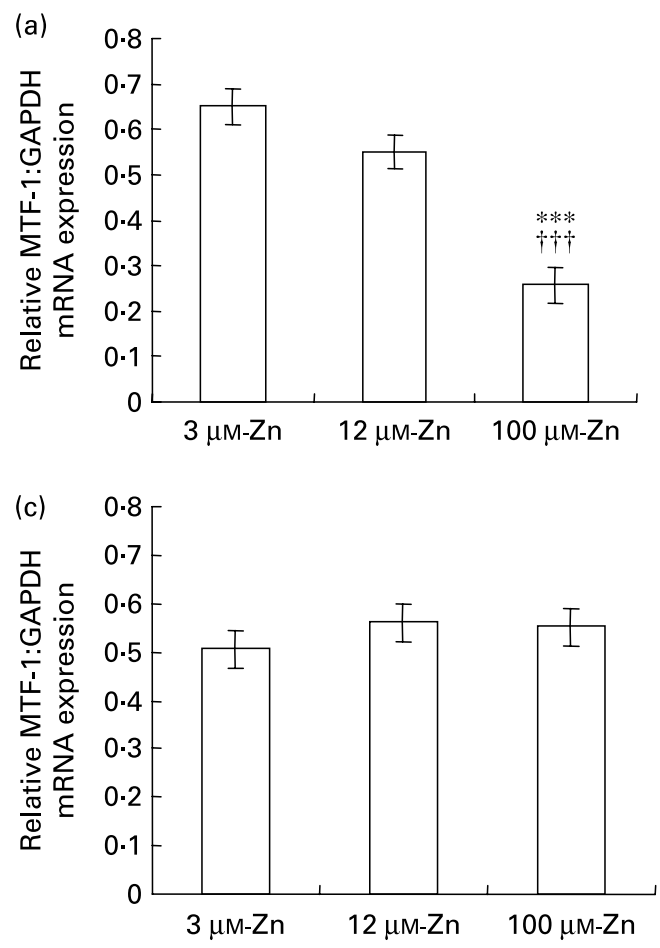

Regulation of metal response element binding transcription factor (MTF)-1 and MTF-2 mRNA by zinc in Caco-2 and JAR cells

Differential sensitivity of Zn-responsive transcription factors may in part explain differences in gene responses to $\mathrm{Zn}$ in Caco-2 and JAR cell lines reported in the present and other studies $^{(19,20)}$. We sought to investigate this proposal by examining the effects of $\mathrm{Zn}$ on transcript levels of the $\mathrm{Zn}$ responsive metal response element binding transcription factor (MTF)-1, and its recently identified homologue MTF2. The responses of MTF-1 and MTF-2 to increased extracellular $\mathrm{Zn}$ concentration were measured by real-time RTPCR (Fig. 2). MTF-1 and MTF-2 mRNA were unchanged in both cell lines at $12 \mu \mathrm{M}$ - compared with $3 \mu \mathrm{M}-\mathrm{Zn}$, but were reduced in Caco-2 cells only, and not in JAR cells, at $100 \mu \mathrm{M}-\mathrm{Zn}$. Therefore, the abundance of both transcription factor mRNA were responsive to the extracellular $\mathrm{Zn}$ concentration in the Caco- 2 cell line, but not the JAR cell line.

\section{Discussion}

We used the high-throughput capacity of DNA microarrays to examine gene regulation by $\mathrm{Zn}$ in intestine and placenta, using the human intestinal cell line Caco-2 and the human placental cell line JAR as appropriate models, and examined gene responses to extracellular $\mathrm{Zn}$ concentrations of $12 \mu \mathrm{M}$ and $100 \mu \mathrm{M}$, representative of the $\mathrm{Zn}$ concentrations typically encountered by the placenta and intestine in vivo. In general,
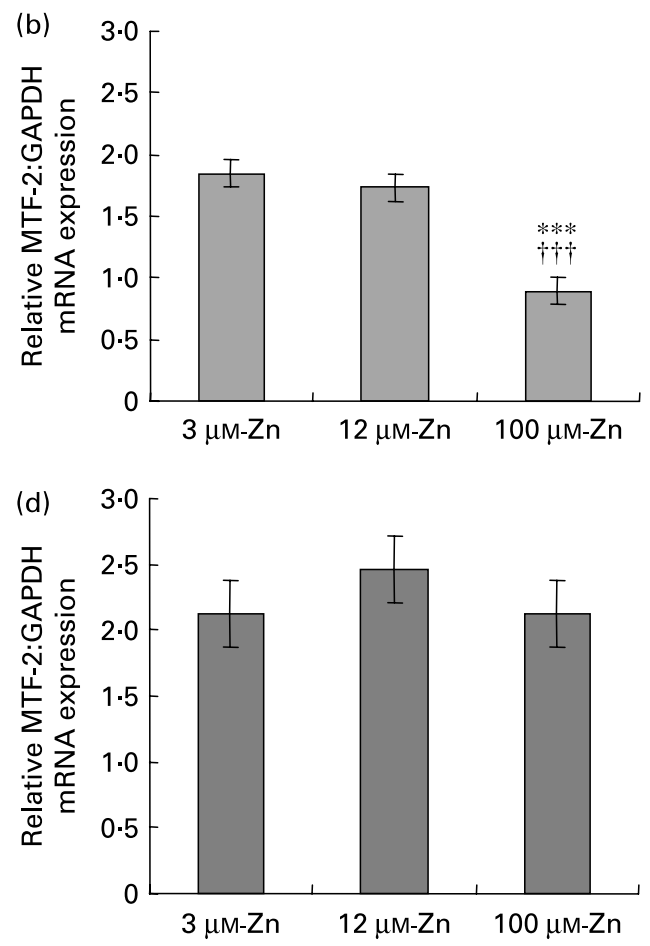

Fig. 2. The effect of extracellular Zn concentration on metal response element binding transcription factor (MTF)-1 (a, c) and MTF-2 (b, d) mRNA expression in Caco-2 (a, b) and JAR (c, d) cells. Cells were cultured for $24 \mathrm{~h}$ at the $\mathrm{Zn}$ concentrations indicated (added as $\mathrm{ZnCl}_{2}$ ) then total RNA was extracted and levels of MTF-1 and MTF-2 mRNA were measured by real-time RT-PCR, using SYBR green fluorescence and the Lightcycler $2 \cdot 0$. Data are expressed relative to glyceraldehyde-3-phosphate dehydrogenase (GAPDH) mRNA levels measured in the same samples. Values are means ( $n 6)$, with standard errors represented by vertical bars. Statistical analysis was by one-way ANOVA followed by Bonferroni's multiple comparisons test. ${ }^{\star \star \star}$ Mean value was significantly different from that at $3 \mu \mathrm{M}-$ $\mathrm{Zn}(P<0.001)$. ††† Mean value was significantly different from that at $12 \mu \mathrm{M}-\mathrm{Zn}(P<0.001)$. 
magnitudes of gene responses were modest and, with the exception of the metallothionein genes, all changes were less than 2-fold. These observations are consistent with results of other microarray studies, which report moderate gene-regulatory effects of both elevated and reduced $\mathrm{Zn}$ availability ${ }^{(6,8)}$. The use of a fold change cut-off is commonly employed as a method for classification of regulated genes in microarray experiments, including several examples of studies using DNA microarrays to identify Zn-regulated genes ${ }^{(5,8-10,13)}$. The choice of which fold change cut-off to use is somewhat arbitrary and a recent report highlighted the fact that using arbitrary threshold criteria can preclude changes with functional importance from consideration, as genes with little inherent variation, but expression ratios just below the cutoff, would be disregarded unnecessarily ${ }^{(6)}$. In view of this argument, we chose to use an alternative approach to identify genes differentially expressed, whereby the threshold cut-off was selected based on the variability of the data, allowing identification of small but significant changes in gene expression. The variance of the normalised set of housekeeping genes was used to generate an estimate of expected variance for the dataset, leading to predicted $95 \% \mathrm{CI}$, and genes with expression ratios outside these CI were selected as differentially expressed. This approach has been used in other low-density microarray studies ${ }^{(24,25)}$ and measurement of variability of the data has been used as a technique to identify Zn-regulated genes in rat liver and jejunum ${ }^{(11)}$. Statistical analysis of large datasets also requires consideration of the problems associated with multiple hypothesis testing, which results in the generation of false positives (type I errors). To control for false discovery rate we applied a Benjamini-Hochberg multiple testing correction (MTC) to statistical analyses of our microarray data. Although MTC limits identification of false positives, we recognise the possibility that some differentially expressed genes in the array experiments were missed due to the application of this correction.

The Zn supply to enterocytes and placental trophoblasts in vivo is subject to fluctuation, albeit to a different extent in each tissue. Placental trophoblasts are exposed to the $\mathrm{Zn}$ concentration of the blood, which can experience some degree of flux but is generally maintained within a fairly narrow range $(12-15 \mu \mathrm{M})$ and rarely exceeds $20 \mu \mathrm{M}$. In contrast, enterocytes are typically exposed to much higher and more variable $\mathrm{Zn}$ concentrations, potentially exceeding $100 \mu \mathrm{M}$ following a meal or nutrient supplement. In view of the analogous roles of the intestine and placenta in nutrient transfer, we hypothesised that alterations in $\mathrm{Zn}$ supply would induce parallel changes in gene expression in Caco-2 and JAR cells. However, given that each tissue senses $\mathrm{Zn}$ over different concentration ranges, we predicted that response profiles to $\mathrm{Zn}$ in intestinal and placental cells would be analogous, but would occur at different, physiologically relevant $\mathrm{Zn}$ concentrations.

In contrast to these predictions, our array analyses demonstrated that approximately equal numbers of genes were regulated by $\mathrm{Zn}$ in both Caco- 2 and JAR cells under the same conditions, and that fewer genes were regulated at $12 \mu \mathrm{M}$ than at $100 \mu \mathrm{M}-\mathrm{Zn}$ in both cell lines. Additionally, we found a lack of correlation between Zn-responsive genes in Caco-2 and in JAR cells at the two $\mathrm{Zn}$ concentrations employed in the present study. Our observations suggest that, despite the analogous roles of the intestine and placenta in nutrient transfer, Zn may modulate different transcription factors and/or regulatory pathways, leading to the regulation of different subsets of genes, in placental and intestinal cells. We propose a number of possible explanations for this finding. One possibility is that exposure to the same concentration of extracellular $\mathrm{Zn}$ does not result in comparable changes in intracellular $\mathrm{Zn}$ in the two cell lines, as a result of differences in the balance between $\mathrm{Zn}$ uptake, efflux and compartmentalisation by specific transport proteins. In support of this concept, we previously reported differential effects of $\mathrm{Zn}$ on the expression of $\mathrm{Zn}$ uptake and efflux transporters in human intestinal and placental cell lines ${ }^{(19,20)}$. Tissue- or cell typespecific gene regulation by $\mathrm{Zn}$ may also be due to the existence of transcription factors and regulatory elements that are expressed or function only in certain cell types. The best-characterised $\mathrm{Zn}$-responsive transcription factor in mammals is MTF-1, which mediates Zn-induced transcriptional activation by binding to metal response elements in gene proximal promoter regions ${ }^{(26)}$. MTF-1 is involved in Zn-induced transcriptional activation of human metallothionein $2 \mathrm{~A}^{(27)}$ as well as mouse metallothionein $1 / 2^{(28)}$ and the $\mathrm{Zn}$ transporter $\mathrm{ZnT}^{(29)}$. MTF-2 was identified recently as a putative homologue of MTF- $1^{(7)}$ and, although its function remains elusive, MTF-2 and MTF-1 mRNA were decreased and increased respectively in $\mathrm{Zn}$-deficient THP-1 cells ${ }^{(7)}$, suggesting potential reciprocal roles in $\mathrm{Zn}$-regulated gene expression. In the present study we demonstrate that the expression of both MTF-1 and MTF-2 mRNA is decreased in response to elevated extracellular $\mathrm{Zn}(100 \mu \mathrm{M})$ in Caco-2 cells only, and not in JAR cells. We suggest that the differential sensitivity to $\mathrm{Zn}$ of these two transcription factors may explain to some extent the differences between gene regulation in Caco-2 and JAR cells. Since a number of other reports document tissue- or cell type-specific regulation of gene expression by $\mathrm{Zn}$, including variations in the direction and magnitude of change ${ }^{(19,20,30-32)}$, it is possible that the differential sensitivity of MTF-1 and MTF-2 extends to other tissues and cell types.

In addition we present evidence that cell type-specific responses of specific genes to changes in $\mathrm{Zn}$ availability are a consequence of differential sensitivity of the $\mathrm{Zn}$-sensing mechanism(s) in each cell type. Using a reporter gene approach, in the present study we demonstrated that transcriptional activation of the highly Zn-responsive human MT2A promoter occurs over different $\mathrm{Zn}$ concentration ranges in Caco-2 and JAR cells, suggesting that there may be different 'set points' for the Zn-sensor in the intestine and placenta.

The results of our microarray analysis offer several opportunities for future investigation of the physiological importance and mechanisms of regulation of specific genes by $\mathrm{Zn}$. For example, a number of genes related to transport or metabolism of $\mathrm{Cu}$ and $\mathrm{Fe}$ were identified as Zn-regulated genes in either Caco-2 or JAR cells. These included the multi-copper ferroxidases hephaestin and ceruloplasmin, the $\mathrm{Cu}$ transporters hCTR2 and ATP7B, the Fe-binding protein transferrin and the Fe-regulated mRNA stability factor IREB2. Regulation of these genes by $\mathrm{Zn}$ is of considerable interest as previous studies have reported adverse effects of elevated $\mathrm{Zn}$ availability on $\mathrm{Cu}$ and $\mathrm{Fe}$ status in both animal models $^{(33)}$ and human subjects ${ }^{(34-36)}$ but the mechanisms through which these effects are mediated are not well understood. It should be noted that the regulatory effects of $\mathrm{Zn}$ on 
the mRNA levels of these genes, as detected by microarray analysis, were confirmed by real-time PCR for hephaestin and IREB2 only. Therefore, further confirmation will be required before the physiological relevance of the remaining genes can be assessed.

Hephaestin, a basolateral membrane ferroxidase responsible for oxidation of $\mathrm{Fe}$ to the ferrous state, is highly expressed in the gut and is required for the release of $\mathrm{Fe}$ from the enterocyte, as illustrated by the anaemic phenotype of sex-linked anaemia (sla) mice that have a mutant form of hephaestin ${ }^{(37)}$. Human studies show an inhibitory effect of high doses of $\mathrm{Zn}$ on intestinal $\mathrm{Fe}$ absorption ${ }^{(38-40)}$. The observed down-regulation of hephaestin transcript levels in $\mathrm{Zn}$-supplemented $(100 \mu \mathrm{M})$ Caco-2 intestinal cells may be a mechanistic explanation for these effects. In support of this view, a previous study reported negative effects of $\mathrm{Zn}$ supplementation on both hephaestin protein expression in the intestine and retention of an oral dose of ${ }^{59} \mathrm{Fe}$ in rat pups given supplemental Zn orally from postnatal day $2^{(41)}$.

Microarray analyses detected up-regulation of the mRNA stability factor IREB2 following treatment of JAR cells with $100 \mu \mathrm{M}$ extracellular $\mathrm{Zn}$ for $24 \mathrm{~h}$ and a similar effect was detected at $12 \mu \mathrm{M}-\mathrm{Zn}$ by real-time RT-PCR. These data indicate that, in placental cells, IREB2 is particularly sensitive to changes in the extracellular $\mathrm{Zn}$ supply. A previous study demonstrated down-regulation of IREB2 expression in human mononuclear THP-1 cells treated with $40 \mu \mathrm{M}-$ $\mathrm{ZnSO}_{4}^{(7)}$, suggesting that the pattern of regulation by $\mathrm{Zn}$ may be cell type specific. IREB2 is expressed in human placenta $^{(42)}$ and may be involved in the post-transcriptional control of placental transferrin receptor 1 , which is responsible for Fe uptake at the villous membrane of the placenta by receptormediated endocytosis ${ }^{(43,44)}$. Elevated $\mathrm{Zn}$ concentrations can affect placental Fe transport, as shown by the increased fetal plasma $\mathrm{Fe}$ and placental $\mathrm{Fe}$ content when pregnant rats were fed $\mathrm{Zn}$-supplemented diets ${ }^{(45)}$. The observed up-regulation of IREB2 expression in JAR cells at elevated extracellular Zn concentrations may be explained by the potential role of IREB2 in the regulation of placental Fe uptake pathways.

The observed apparent differences in gene regulation derived from the microarray analysis and kinetic real-time RT-PCR may be a consequence of the relatively small changes in expression observed, the use of different normalisation methods or the interrogation of different regions of the sequence using the two different techniques, which may lead to the detection of splice-variant-specific effects with only one or other approach. Interestingly, in confirmation of our findings, a recent study of the effect of dietary $\mathrm{Zn}$ deficiency on gene expression in rat hepatocytes reported that the direction of regulation of ceruloplasmin detected by array data was opposite to that observed with Northern blotting ${ }^{(13)}$. Limitations with respect to microarray sensitivity or interrogation of different regions of the coding sequence using microarray hybridisation compared with RT-PCR may also account for the fact that we detected no $\mathrm{Zn}$-dependent change in expression of ZnT1 and ZnT5 mRNA in Caco-2 cells, in contrast to our previous observations made in human intestinal mucosa, where we measured reduced ZnT1 mRNA levels in response to oral $\mathrm{Zn}$ supplementation ${ }^{(46)}$, and in Caco-2 cells, where we measured increased levels of ZnT1 and ZnT5 mRNA at the same concentration of extracellular $\mathrm{Zn}$
$(100 \mu \mathrm{M})^{(20)}$, but over a longer $(3$ or $7 \mathrm{~d})$ period of exposure, which may, itself, be an alternative explanation. Similarly, a time-dependent effect may explain the observation that microarray analysis in the present study detected an increase in ZnT1 mRNA in the placental cell line JAR after exposure to $100 \mu \mathrm{M}-\mathrm{Zn}$ for $24 \mathrm{~h}$, whilst we previously detected no change in ZnT1 expression in JAR cells exposed to $100 \mu \mathrm{M}$ $\mathrm{Zn}$ for $7 \mathrm{~d}^{(19)}$.

Two other Zn-regulated genes identified by microarray analyses merit further comment. The first of these is liver fatty acid-binding protein, which was down-regulated by 1.4-fold in Caco- 2 cells treated with $12 \mu \mathrm{M}-\mathrm{Zn}$ for $24 \mathrm{~h}$. Previous microarray analyses showed that mRNA levels of a number of genes involved in lipid metabolism, including liver fatty acid-binding protein, were modulated by low $\mathrm{Zn}$ status in rats $^{(12,13)}$. Regulation of liver fatty acid-binding protein expression by $\mathrm{Zn}$ supply may in part provide a mechanistic explanation for reports that $\mathrm{Zn}$-deficient rats develop fatty livers, characterised by increased TAG accumulation ${ }^{(47,48)}$ The second gene is the $\mathrm{Na}^{+} / \mathrm{H}^{+}$exchanger $\mathrm{NHE} 1$, which was up-regulated by 1.5 -fold in Caco- 2 cells exposed to $100 \mu \mathrm{M}-\mathrm{Zn}$ for $24 \mathrm{~h}$. Consistent with this finding, previous studies demonstrated that elevated extracellular $\mathrm{Zn}$ concentrations $(>50 \mu \mathrm{M})$ activated $\mathrm{Na}^{+} / \mathrm{H}^{+}$exchange in HT-29 human colonic cells and enhanced recovery from acidic $\mathrm{pH}^{(49)}$.

In summary, the data presented in the present study demonstrate that human intestinal and placental cells display differential transcriptomic responses to changes in $\mathrm{Zn}$ availability. These effects may in part be attributed to transcription factors whose activities are dependent on whether the intracellular environment is intestinal or placental. The response profile of the human MT2A promoter to $\mathrm{Zn}$ indicates that there may be a different set-point for the $\mathrm{Zn}$ sensor in these two tissues. Data from microarray analyses suggest that different genes respond to changes in $\mathrm{Zn}$ availability in intestinal cells compared with placental cells and a number of these genes represent targets for future research into nutrient interactions between $\mathrm{Zn}$ and other essential metals. An understanding of these interactions is essential for assessing the potential risks to nutritional status posed by dietary $\mathrm{Zn}$ supplementation.

\section{Acknowledgements}

The present study was supported by the United Kingdom Biotechnology and Biological Sciences Research Council Grant 13D/18271 (to D. F. and J. C. M.) and by a research studentship from the Medical Research Council (to K. A. J.). We would also like to acknowledge financial support from the Rank Prize Funds.

K. A. J. was responsible for all experimental and analytical work, other than that attributed to other authors as follows, and for the initial preparation of the manuscript. R. A. V. was responsible for the identification of genes to include on the microarrays and for preliminary optimisation of microarray hybridisation procedures. J. A. M. carried out and analysed experiments presented as Fig. 2. D. C. S. provided advice and support concerning microarray analysis. J. C. M. provided support and guidance throughout the study, including the initial study design, and provided advice on preparation of the manuscript. D. F. provided support and guidance 
throughout the study, including the initial study design, and contributed to the preparation of the manuscript.

The authors have no conflicts of interest to declare.

The supplementary material (Supplementary Table 1) mentioned in this article can be found at http://journals.cambridge. org/bjn

\section{References}

1. Vallee BL \& Falchuk KH (1993) The biochemical basis of zinc physiology. Physiol Rev 73, 79-118.

2. Cousins RJ (1998) A role of zinc in the regulation of gene expression. Proc Nutr Soc 57, 307-311.

3. Dreosti IE (2001) Zinc and the gene. Mutat Res 475, 161-167.

4. Mackay JP \& Crossley M (1998) Zinc fingers are sticking together. Trends Biochem Sci 23, 1-4.

5. Beck FW, Li Y, Bao B, et al. (2006) Evidence for reprogramming global gene expression during zinc deficiency in the HUT-78 cell line. Nutrition 22, 1045-1056.

6. Blanchard RK, Moore JB, Green CL, et al. (2001) Modulation of intestinal gene expression by dietary zinc status: effectiveness of cDNA arrays for expression profiling of a single nutrient deficiency. Proc Natl Acad Sci U S A 98, 13507-13513.

7. Cousins RJ, Blanchard RK, Popp MP, et al. (2003) A global view of the selectivity of zinc deprivation and excess on genes expressed in human THP-1 mononuclear cells. Proc Natl Acad Sci U S A 100, 6952-6957.

8. Kindermann B, Doring F, Fuchs D, et al. (2005) Effects of increased cellular zinc levels on gene and protein expression in HT-29 cells. Biometals 18, 243-253.

9. Kindermann B, Doring F, Pfaffl M, et al. (2004) Identification of genes responsive to intracellular zinc depletion in the human colon adenocarcinoma cell line HT-29. J Nutr 134, $57-62$.

10. Moore JB, Blanchard RK, McCormack WT, et al. (2001) cDNA array analysis identifies thymic LCK as upregulated in moderate murine zinc deficiency before T-lymphocyte population changes. J Nutr 131, 3189-3196.

11. Pfaffl MW, Gerstmayer B, Bosio A, et al. (2003) Effect of zinc deficiency on the mRNA expression pattern in liver and jejunum of adult rats: monitoring gene expression using cDNA microarrays combined with real-time RT-PCR. J Nutr Biochem 14, 691-702.

12. tom Dieck H, Doring F, Fuchs D, et al. (2005) Transcriptome and proteome analysis identifies the pathways that increase hepatic lipid accumulation in zinc-deficient rats. $J$ Nutr $\mathbf{1 3 5}$, 199-205.

13. tom Dieck H, Doring F, Roth HP, et al. (2003) Changes in rat hepatic gene expression in response to zinc deficiency as assessed by DNA arrays. J Nutr 133, 1004-1010.

14. Yamada H, Suzuki K \& Koizumi S (2007) Gene expression profile in human cells exposed to zinc. J Toxicol Sci 32, 193-196.

15. Krebs NF (2000) Overview of zinc absorption and excretion in the human gastrointestinal tract. J Nutr 130, 1374S-1377S.

16. Blanchard RK \& Cousins RJ (1996) Differential display of intestinal mRNAs regulated by dietary zinc. Proc Natl Acad Sci U S A 93, 6863-6868.

17. Blanchard RK \& Cousins RJ (2000) Regulation of intestinal gene expression by dietary zinc: induction of uroguanylin mRNA by zinc deficiency. $J$ Nutr 130, 1393S-1398S.

18. Tamura T \& Goldenberg M (1996) Zinc nutriture and pregnancy outcome. Nutr Res 16, 139-181.

19. Ford D (2004) Intestinal and placental zinc transport pathways. Proc Nutr Soc 63, 21-29.
20. Cragg RA, Christie GR, Phillips SR, et al. (2002) A novel zinc-regulated human zinc transporter, hZTL1, is localized to the enterocyte apical membrane. J Biol Chem 277, 22789-22797.

21. Hotz C, Peerson JM \& Brown KH (2003) Suggested lower cutoffs of serum zinc concentrations for assessing zinc status: reanalysis of the second National Health and Nutrition Examination Survey data (1976-1980). Am J Clin Nutr 78, 756-764.

22. Helston RM, Phillips SR, McKay JA, et al. (2007) Zinc transporters in the mouse placenta show a coordinated regulatory response to changes in dietary zinc intake. Placenta 28, 437-444.

23. Jackson KA, Helston RM, McKay JA, et al. (2007) Splice variants of the human zinc transporter ZnT5 (SLC30A5) are differentially localised and regulated by zinc through transcription and mRNA stability. J Biol Chem 282, 10423-10431.

24. de Longueville F, Atienzar FA, Marcq L, et al. (2003) Use of a low-density microarray for studying gene expression patterns induced by hepatotoxicants on primary cultures of rat hepatocytes. Toxicol Sci 75, 378-392.

25. de Longueville F, Surry D, Meneses-Lorente G, et al. (2002) Gene expression profiling of drug metabolism and toxicology markers using a low-density DNA microarray. Biochem Pharmacol 64, 137-149.

26. Andrews GK (2001) Cellular zinc sensors: MTF-1 regulation of gene expression. Biometals 14, 223-237.

27. Koizumi S, Suzuki K, Ogra Y, et al. (1999) Transcriptional activity and regulatory protein binding of metal-responsive elements of the human metallothionein-IIA gene. Eur J Biochem 259, 635-642.

28. Heuchel R, Radtke F, Georgiev O, et al. (1994) The transcription factor MTF-1 is essential for basal and heavy metalinduced metallothionein gene expression. EMBO $J \mathbf{1 3}$, $2870-2875$.

29. Langmade SJ, Ravindra R, Daniels PJ, et al. (2000) The transcription factor MTF-1 mediates metal regulation of the mouse ZnT1 gene. J Biol Chem 275, 34803-34809.

30. Liuzzi JP, Blanchard RK \& Cousins RJ (2001) Differential regulation of zinc transporter 1,2 , and 4 mRNA expression by dietary zinc in rats. $J$ Nutr $131,46-52$.

31. Liuzzi JP, Bobo JA, Lichten LA, et al. (2004) Responsive transporter genes within the murine intestinal-pancreatic axis form a basis of zinc homeostasis. Proc Natl Acad Sci U S A 101, $14355-14360$

32. Pfaffl MW \& Windisch W (2003) Influence of zinc deficiency on the mRNA expression of zinc transporters in adult rats. $J$ Trace Elem Med Biol 17, 97-106.

33. Cox DH, Schlicker SA \& Chu RC (1969) Excess dietary zinc for the maternal rat, and zinc, iron, copper, calcium, and magnesium content and enzyme activity in maternal and fetal tissues. $J$ Nutr 98, 459-466.

34. Fischer PW, Giroux A \& L'Abbe MR (1984) Effect of zinc supplementation on copper status in adult man. Am J Clin Nutr 40, 743-746.

35. Yadrick MK, Kenney MA \& Winterfeldt EA (1989) Iron, copper, and zinc status: response to supplementation with zinc or zinc and iron in adult females. Am J Clin Nutr 49, $145-150$.

36. Donangelo CM, Woodhouse LR, King SM, et al. (2002) Supplemental zinc lowers measures of iron status in young women with low iron reserves. J Nutr 132, 1860-1864.

37. Vulpe CD, Kuo YM, Murphy TL, et al. (1999) Hephaestin, a ceruloplasmin homologue implicated in intestinal iron transport, is defective in the sla mouse. Nat Genet 21, 195-199.

38. Whittaker P (1998) Iron and zinc interactions in humans. Am J Clin Nutr 68, 442S-446S. 
39. Sandstrom B (2001) Micronutrient interactions: effects on absorption and bioavailability. Br J Nutr 85, Suppl. 2, S181-S185.

40. Olivares M, Pizarro F \& Ruz M (2007) Zinc inhibits nonheme iron bioavailability in humans. Biol Trace Elem Res 117, 7-14.

41. Kelleher SL \& Lonnerdal B (2006) Zinc supplementation reduces iron absorption through age-dependent changes in small intestine iron transporter expression in suckling rat pups. J Nutr 136, 1185-1191.

42. Bradley J, Leibold EA, Harris ZL, et al. (2004) Influence of gestational age and fetal iron status on IRP activity and iron transporter protein expression in third-trimester human placenta. Am J Physiol Regul Integr Comp Physiol 287, R894-R901.

43. McArdle HJ, Danzeisen R, Fosset C, et al. (2003) The role of the placenta in iron transfer from mother to fetus and the relationship between iron status and fetal outcome. Biometals 16, 161-167.

44. Verrijt CE, Kroos MJ, Huijskes-Heins MI, et al. (1999) Accumulation and release of iron in polarly and non-polarly cultured trophoblast cells isolated from human term placentas. Eur J Obstet Gynecol Reprod Biol 86, 73-81.

45. Barone A, Ebesh O, Harper RG, et al. (1998) Placental copper transport in rats: effects of elevated dietary zinc on fetal copper, iron and metallothionein. J Nutr 128, 1037-1041.

46. Cragg RA, Phillips SR, Piper JM, et al. (2005) Homeostatic regulation of zinc transporters in the human small intestine by dietary zinc supplementation. Gut 54, 469-478.

47. Eder K \& Kirchgessner M (1995) Zinc deficiency and activities of lipogenic and glycolytic enzymes in liver of rats fed coconut oil or linseed oil. Lipids 30, 63-69.

48. Eder K \& Kirchgessner M (1993) The effect of zinc depletion on the fat content and fatty acid composition of the liver and brain in forcibly fed rats (article in German). Z Ernahrungswiss 32, 187-197.

49. Azriel-Tamir H, Sharir H, Schwartz B, et al. (2004) Extracellular zinc triggers ERK-dependent activation of $\mathrm{Na}^{+} / \mathrm{H}^{+}$exchange in colonocytes mediated by the zinc-sensing receptor. $J$ Biol Chem 279, 51804-51816. 